

\title{
Presbeutikoi and Enteuktikoi Logoi in Hellenistic Interstate Relations. Some Further Thoughts from an Epigraphical Perspective (c. 306-205 B.C.) \\ Davide Amendola
}

\section{- To cite this version:}

Davide Amendola. Presbeutikoi and Enteuktikoi Logoi in Hellenistic Interstate Relations. Some Further Thoughts from an Epigraphical Perspective (c. 306-205 B.C.). KTĖMA Civilisations de l'Orient, de la Grèce et de Rome antiques, 2019, La rhétorique de la diplomatie en Grèce ancienne, 44, pp.87-103. halshs-02444106

\author{
HAL Id: halshs-02444106 \\ https://shs.hal.science/halshs-02444106
}

Submitted on 17 Jan 2020

HAL is a multi-disciplinary open access archive for the deposit and dissemination of scientific research documents, whether they are published or not. The documents may come from teaching and research institutions in France or abroad, or from public or private research centers.
L'archive ouverte pluridisciplinaire HAL, est destinée au dépôt et à la diffusion de documents scientifiques de niveau recherche, publiés ou non, émanant des établissements d'enseignement et de recherche français ou étrangers, des laboratoires publics ou privés. 



\section{CIVILISATIONS DE L'ORIENT, DE LA GRÈCE ET DE ROME ANTIQUES}

\section{La rhétorique de la diplomatie en Grèce ancienne}

Cinzia BeARzot, Laura Loddo

Laura LoDDo

Cinzia BeArzot

Paolo A. Tuci

Francesca Gazzano

Nicholas D. Cross

Davide Amendola

Jonathan R. W. PraG

Lorenzo CAMPAGNA

Cristina SORACI

Edith Foster

Walter LAPINI

Sylvain PERROT

Gianpaolo Urso

Anne JACQuemin
Political Exiles and Their Use of Diplomacy in Classical Greece

À propos du parallélisme entre deux discours d'ambassade à Sparte (Xén. Hell. V, 2, 12-19 et VI, 1, 4-16). 23

The Speeches of Theban Ambassadors in Greek Literature (404-362 B.C.)................ 33

Greek Ambassadors and the Rhetoric of Supplication. Some Notes ............................ 53

The (Im)balance of Power. Demosthenes' Complex Case

for an Alliance with the Megalopolitans.....

Presbeutikoi and Enteuktikoi Logoi in Hellenistic Interstate Relations.

Some Further Thoughts from an Epigraphical Perspective (c. 306-205 B.C.). 87

\section{Sicile hellénistique et romaine}

I.Sicily, Open Scholarship, and the Epigraphic Landscape of Hellenistic/Roman Sicily.

Trasformazioni urbanistiche in Sicilia alle origini della Provincia.

Riflessioni sul ruolo di Roma.....

Cultes et politique dans la Sicile du i ${ }^{\text {er }}$ siècle av. J.-C.

Le cas de la Vénus Érycine et de la Cérès d'Henna

\section{Varia}

Athens' Political Failures in the Central Chapters of Book 4 of Thucydides 163

Note interpretative e testuali alla col. XXII del Papiro di Derveni

La place de la musique dans la politique culturelle de Téos

dans la première moitié du $\mathrm{II}^{\mathrm{e}}$ siècle avant notre ère

Catilina legatus. Considerazioni su un discusso frammento sallustiano.

La dédicace aux Muses d'Eurydice fille de Sirrhas

(Plutarque, Sur l'éducation des enfants, 20) 


\section{Presbeutikoi and Enteuktikoi Logoi in Hellenistic Interstate Relations Some Further Thoughts from an Epigraphical Perspective (c. 306-205 B.C.)*}

RÉsumÉ-. L'importance croissante des interactions diplomatiques dans le monde hellénistique a conduit certains historiens et rhétoriciens à développer et à manipuler la tripartition aristotélicienne des genera dicendi afin d'y inclure les discours des ambassadeurs. S'appuyant principalement sur la documentation épigraphique, qui, malgré son importance pour la reconstruction de l'évolution de la diplomatie grecque ancienne, a été largement négligée jusqu'à présent, cet article a pour but de contribuer à la définition des caractéristiques distinctives de la rhétorique diplomatique au $\mathrm{III}^{\mathrm{e}}$ siècle av. J.-C. en examinant des inscriptions qui préservent les résumés ou des commentaires des présentations orales des ambassadeurs devant leur public.

Mотs-CLÉs-. diplomatie grecque, relations internationales à l'époque hellénistique, épigraphie grecque, éloquence hellénistique, Polybe, rhétorique grecque

Aвstract-. The increasing importance of diplomatic interactions in the Hellenistic world led some historians and rhetoricians to expand and manipulate Aristotle's tripartition of the genera dicendi so as to include the ambassadorial address. Building primarily on epigraphic evidence, which, despite being instrumental in reconstructing the development of ancient Greek diplomacy, has been largely neglected, this paper aims to contribute to a better understanding of the characteristics of ambassadorial rhetoric in the third century BC by examining some inscriptions that preserve summaries of (or comment on) the envoys' oral presentations before their audiences.

KeYwordS-. Greek diplomacy, Hellenistic interstate relations, Greek epigraphy, Hellenistic oratory, Polybius, Greek rhetoric

1. Recent decades have seen an explosion of research on Hellenistic cities ${ }^{1}$, which in turn, inspired by Louis Robert's famous claim that the polis did not die at Chaeronea ${ }^{2}$, has led to a

\footnotetext{
* The present article summarises some results of the research conducted within the project Greek Envoys and Diplomacy in the Hellenistic and Roman World (GED), run by the Scuola Normale Superiore of Pisa and directed by Anna Magnetto. Its primary purpose is the creation of a comprehensive prosopography, along with a digital database, of all Greek envoys in the period between the mid-fourth century $\mathrm{BC}$ and the end of the third century $\mathrm{AD}$ in an attempt to prioritise the role of the poleis. An early version of this paper was given at the 11th Celtic Conference in Classics (University of St Andrews, 11th-14th July 2018), Panel no. 10 (How diplomacy was characterized in ancient Greek historiography and oratory). I would like to thank the organisers, Cinzia Bearzot and Laura Loddo, and audience members, who provided helpful feedback. Andrew Erskine, Anna Magnetto and Donatella Erdas read an earlier draft of the article and gave me much useful advice. I am also grateful to the anonymous Ktèma referees for insightful comments. Any mistakes that remain are my own. Inscriptions are abbreviated after $S E G$.
}

(1) On this point, see lastly the essays collected by Börm-LuraGHi 2018.

(2) Cf. Pernot 2005, p. 74-82. 
thorough reassessment of the afterlife of ancient democracies in the post-Classical world ${ }^{3}$. The attempt to provide a systematic reappraisal of the ways in which Greek political life 'survived' and developed after Alexander through the analysis of the abundant epigraphical materials from all across the Hellenistic world has been accompanied by an upsurge of scholarly interest in investigating the concrete institutional arrangement of civic communities ${ }^{4}$, as well as the mechanisms of their decision-making processes and external policies.

In particular, after a series of foundational studies on ancient Greek diplomacy in which the post-Classical period was substantially set aside due to the alleged subordination of the poleis to Mediterranean suprapowers ${ }^{5}$, increasing attention has recently been devoted to the modifications that the structures of interstate interactions underwent. This was partly a result of an era of intense and enormously expanded diplomatic activity, but was also due to historical processes such as the rise of federal states and the emergence of powerful civic élites, which force us to understand Hellenistic diplomatic protocols against a background different than that observed in the 5th and 4 th centuries BC. Notwithstanding, it is undeniable that-because, in part, of a revival of interest in ancient court studies-more recent approaches to post-Classical interstate exchanges have centred almost exclusively on king-initiated diplomacy, thus disregarding the complex world of civic communities ${ }^{6}$. As a result, despite this renewed scholarly interest, much remains to be done, particularly as concerns the contribution of epigraphical materials to the analysis of Hellenistic international relations, a type of evidence that scholars have begun to explore seriously only in the last few years ${ }^{7}$. Moreover, due to the revived debate on the role played by political eloquence in the life of the post-Classical poleis, some attempts have recently been made to underscore the oratorical aspects of Hellenistic interstate communication ${ }^{8}$.

Starting from the assumption that epigraphic materials are particularly accurate in depicting the constantly shifting hierarchies of power within the post-Alexander world ${ }^{9}$, which Arthur Eckstein

(3) Recent bibliography on Hellenistic democracies is extensive: see e.g., with further references, ManN-Scholz 2012.


FRÖHLICH 2004.

(5) AdCock-Mosley 1975, the standard account of diplomacy in ancient Greece, pays scarce attention to the centuries between Alexander and Augustus (see also Mosley 1973), and the same holds true for the more recent volumes by Piccirilli 2002a and Low 2007. At any rate, the previous neglect of Hellenistic diplomacy should not be overstated, for in works such as KLOSE 1972, KIENAST 1973 (which proves still invaluable for most of the issues concerning Greek $\pi \rho \varepsilon \sigma \beta \varepsilon \tilde{a}$ ), Giovannini 2007 and Koenn 2007, the post-Classical period receives extensive treatment. See, more recently, MARTínEZ Morcillo 2016; Kralli 2017.

(6) Cf. Olshausen 1974; Paschidis 2008; Grainger 2017. Further issues relating to royal envoys are explored by Paschidis 2013, Savalli-Lestrade 2017 and Buraselis 2018. On Hellenistic courts, see now Erskine et alii 2017. For the creation of institutional networks between poleis in the Hellenistic age, see the classic essay by Ma 2003; for further application of the peer polity interaction model, see now DAUBNER 2018.

(7) On this point, see also Rubinstein 2013, esp. p. 165-167.

(8) Kremmydas-Tempest 2013; Edwards 2016.

(9) Cases in point are the foundation document of the Leukophryena (I.Magnesia 16, 11. 30-32: $\dot{\alpha} \pi \circ \delta \varepsilon \xi \alpha \mu \varepsilon \dot{\varepsilon} \omega \nu \tau \tilde{\omega} \mu$

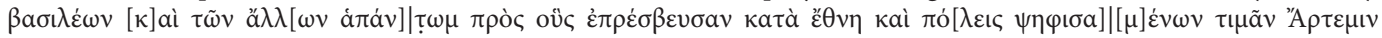

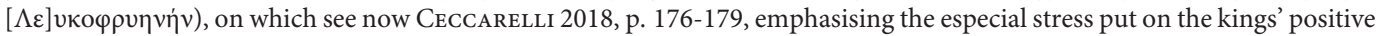
answers also from the material and formal standpoints, as well as the letter of Ptolemy III recognising the inviolability of


of Staatsverträge 492, 11. 11-12. Note that a Greek view on the changes that interstate relations underwent after Roman intervention is clearly reflected in the honorary decree for Menippos of Colophon (SEG XXXIX 1244, after 120/119 BC,

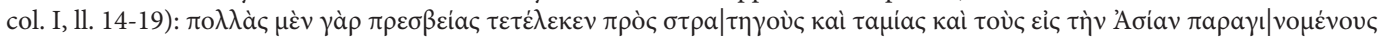



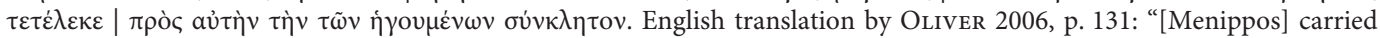
out many embassies to governors (lit. generals) and quaestors (lit. treasurers) and those of the Romans present in Asia, and many to the Attalid royalty and not a small number of poleis. But the most important embassies concerning the most 
has labelled "Mediterranean anarchy"10, the purpose of this paper is to explore some aspects of Greek diplomatic rhetoric between the formal establishment of the Hellenistic kingdoms (306-304


a guarantor (according to the traditional interpretation of Elias Bickerman) ${ }^{11}$, from an epigraphical standpoint. Such chronological boundaries have primarily been chosen because, unlike Polybius'


works better as a lower limit for the study of Greek diplomatic practices before they were affected by Roman intervention in the Mediterranean East ${ }^{12}$. In this article, I intend to address certain issues posed by the epigraphic evidence when attempting to reconstruct contents and features of the Hellenistic ambassadorial addresses, as the documents issued by the recipient communities in response to a diplomatic approach do not usually provide detailed summaries of the envoys' requests, nor commentaries upon their presentations. However, building on a small selection of inscriptions, I shall isolate certain relevant exceptions to this trend that can be usefully contrasted with Polybius. Such a comparison of epigraphic materials with contemporary historiography stems from the assumption entertained by the Roberts several years ago that in the Hellenistic period the interaction between the historians' language and epigraphic texts is more productive than in the past, as clearly revealed, for instance, by the widespread phenomenon of 'biographical' $\psi \eta \varphi$ í $\mu \alpha \tau \alpha$ in honour of eminent citizens ${ }^{13}$.

2. In discussing the issue of the emergence of the ambassador's speech as a new oratorical category, most scholars argue that Polybius, by associating it with battle exhortations ( $\pi \alpha \rho a \kappa \lambda \eta \dot{\sigma \varepsilon \varepsilon \varsigma) ~}$ and symbouleutic oratory ( $\delta \eta \mu \eta \gamma o p i a l)$ in his bitter attacks on Timaeus (which Diodorus somehow echoes in the proem to book XX), was the first to deal with this innovation ${ }^{14}$. On closer inspection, however, this claim is essentially wrong. In a quite obscure passage of Philodemus' Rhetoric, the Peripatetic philosopher, orator and statesman Demetrius of Phalerum is credited with having

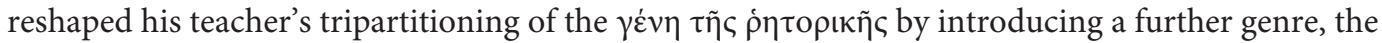


with rulers in diplomatic missions" ${ }^{\prime 2}$. That Demetrius dealt with such an issue comes as no surprise

pressing subjects that he completed were to the very Senate of those who have hegemonia". Cf. FERrary 2016, p. 183, who rightly speaks of a " gradation bien soulignée".

(10) ECKSTein 2006, esp. p. 79-117.

(11) Momigliano 1940 [= 1992], p. 490. On the implications of the peace of Phoenice, see, e.g., Eckstein 2008, p. 91-116; DMitriev 2011, p. 167-181, who rejects Bickerman's interpretation; Thornton 2014, esp. p. 43-47.

(12) The same periodisation has been adopted by, among others, MAgnetto 1997, Giovannini 2007 and Paschidis 2008. The implications of Roman intervention for Greek interstate communication and the coalescence between Greek and Roman diplomatic practices between the third and the second centuries BC have recently been explored in a number of studies: in addition to Ferrary 2016, see especially the essays gathered by EILERS 2009 and Grass-STOUdER 2015.

(13) For a recent application of the same approach, see e.g. Сhaniotis 2013a; Gray 2013, esp. p. 149-162. All relevant biographical decrees from the Hellenistic period are now collected by Forster 2018.

(14) Plb. 12.25a.3 (= PePe 2013, T 99); cf. $12.25 \mathrm{i} .3$ (= PePe 2013, T 100); D.S. 20.1.2 Durvye (= PePe 2013, T 135): kaítol

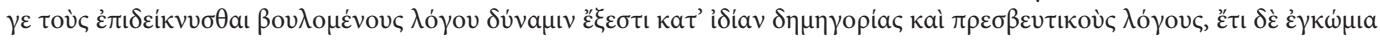


who wish to display rhetorical prowess to compose by themselves public discourses and speeches for ambassadors, likewise

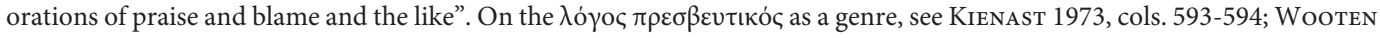
1973; Nelson 2005, p. 217-218; Pepe 2013, p. 329-335; Rubinstein 2016, p. 79-82; Ferrary 2016, p. 186-190.

(15) Phld. Rh. IV, P.Herc. 1673/1007, col. XLIa , 1l. 6-18, vol. I, p. 222 Sudahus (= PePe 2013, T 97; see also p. 299-






is that Demetrius of Phalerum, along with the sophistic (= epideictic) kind of speeches, adds to the deliberative and forensic (kinds) the (kind of speech) serving for encounters with all people. Now, if he takes (this) as the (kind of speech) serving for 
when one recalls his participation in the Athenian negotiations with Antipater and Craterus after their victory in the Lamian War. At any rate, assuming that Philodemus' rephrasing of the source's words is reliable, it might reasonably be surmised that it was the intrusion of Alexander's successors on the diplomatic scene which urged Demetrius to think of the speeches held before a king (within the context of those $\dot{\varepsilon} v \tau \varepsilon \dot{\xi} \xi \varepsilon$ c referred to by a number of inscriptions) as a new oratorical category ${ }^{16}$. The implications of this choice become even clearer if one considers that the two major fourth-century rhetorical treatises have nothing specific to say about envoys' oratorical performances ${ }^{17}$. Further stages of the trajectory followed by the $\pi \rho \varepsilon \sigma \beta \varepsilon v \tau$ เ rhetorical development include Menander Rhetor's treatment of the ambassadorial address as one of the epideictic species ( $3 \mathrm{rd}$ c. CE) and Pollux' assimilation of envoys to orators in the section of his Onomasticon (2nd c. CE) dedicated to $\dot{\eta} \eta \omega \rho$, where $\pi \rho \varepsilon \sigma \beta \varepsilon v \tau \eta \dot{~}, \pi \rho \varepsilon \sigma \beta \varepsilon \dot{\alpha} \alpha$ and $\pi \rho \varepsilon \dot{\varepsilon} \sigma \varepsilon v \sigma \iota \varsigma$ are

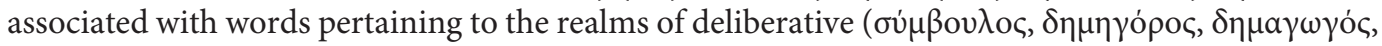

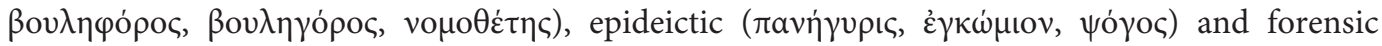

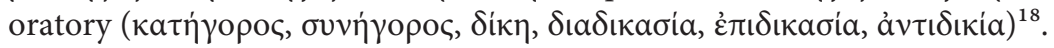


appeared may be gained from a close examination of Polybius ${ }^{19}$, who, in addition to addressing the issue as to how $\lambda$ ó ${ }^{\circ}$ o should be rephrased in historical works from a genuinely Thucydidean perspective $e^{20}$, had in some cases the opportunity of accessing written versions of speeches published by the envoys themselves, as is the case with the Rhodian Astymedes' oration ${ }^{21}$. Notwithstanding, a difficulty arises with the choice of distinguishing between ambassadorial addresses and $\delta \eta \mu \eta \gamma o$ pial $^{22}$, two $\gamma \dot{\varepsilon} v \eta$ that should have been considered as one and the same, their aim being primarily that of

encounters with the masses and as that (serving for encounters) with rulers in diplomatic missions, let us grant him that for the moment". Cf. Phld. Rh. II, P.Herc. 1672, col. XXXI, 1l. 2-5 Longo Auricchio (= Pepe 2013, T 109).
















XII 4, 210, 1l. 4-8.

(17) As recently pointed out by RuBINSTEIN 2016, p. 80-81. However, the author of the Rhetoric to Alexander (30.2-3


comparing the arguments that Aristotle (Rh. 1359b19-23) and the Rhetoric to Alexander (2.2 Chiron, 1423a20-26) consider

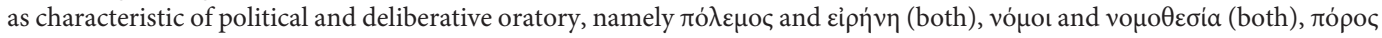

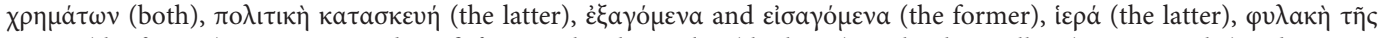

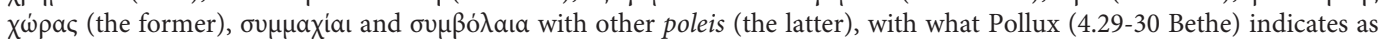

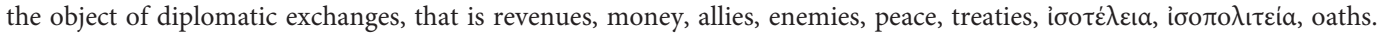
For another cluster of words revolving around $\pi \rho \varepsilon \dot{\sigma} \sigma \varepsilon \varepsilon \varsigma$, see Poll. 8.137-139.

(18) Poll. 4.25-26 Bethe.

(19) According to the figures given by Zecchins 2005, p. 11 (= Zecchini 2018, p. 87), the Histories contains references to 433 missions. However, it must be borne in mind that, barring the ultimatum delivered by the Roman envoys at Carthage (Plb. 3.33) and the speech by Agelaus (5.104), all accounts of ambassadorial addresses (either in oratio recta or in oratio obliqua) come from fragments preserved by the Excerpta Constantiniana. For the reconstruction of a typical ambassadorial address from the Hellenistic period, see Wooten 1973, p. 210-211.

(20) It is not possible here to give a full account of the innumerable issues raised by Polybius' attitude to speeches. A thorough reassessment from a methodological standpoint is now provided by Nicolai 2018; cf. PaUsCH 2018. On the

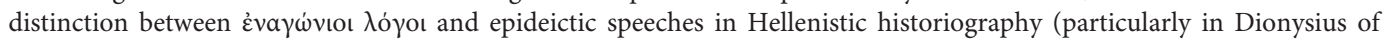
Halicarnassus), see SACKs 1986, p. 388-392.

(21) Plb. 30.4.13-14.

(22) Cf. Rubinstein 2016, p. 79. 
persuading to (or dissuading from) specific actions. The contradiction becomes even clearer when one considers that, in the context of the heated debate before the Spartan assembly between the envoys Chlaeneas and Lyciscus (Plb. 9.28-39), imagined as having taken place in $210 \mathrm{BC}$, after the ratification of Aetolia's alliance with Rome in 212 BC (Staatsverträge 536), the latter uses the label of $\delta \eta \mu \eta \gamma$ opia while referring to the speech of the former, exactly as Aeschines and Demosthenes did. Furthermore, whereas the notorious speech of the Aetolian Agelaus in the context of Philip V's peace iniative at Naupactus in $217 \mathrm{BC}$ (Plb. 5.104.1-11), as well as that delivered by Thrasycrates of Rhodes in the summer of $207 \mathrm{BC}$ during the Panaetolian assembly at the federal temple of Apollo at Thermos (11.4-6), resembles in every respect traditional $\delta \eta \mu \eta \gamma o \rho i \alpha$ due to their projection to the future ${ }^{23}$, the a $v \tau \tau \imath \lambda o \gamma$ ia between the Aetolian Chlaeneas and the Acarnanian Lyciscus sees the deployment of rhetorical strategies encapsulating two of the main arguments of Hellenistic interstate communication, namely the exploitation of historical proofs and the stress on previous benefactions towards the recipient community ${ }^{24}$. Neither topic is of course wholly new in the realm of ancient diplomatic exchanges, for the occasional recourse to both, albeit to a different extent, is to be observed already in the Classical age ${ }^{25}$. In the Hellenistic period, however, such rhetorical strategies found new nourishment and strength, as clearly shown by epigraphic evidence ${ }^{26}$.

3. It has often been emphasised that most Hellenistic inscriptions concerning diplomatic interactions are too concise to enable one to grasp the details of what envoys actually said in their addresses ${ }^{27}$. In some cases, however, despite the absence of informative summaries of their content, certain information on the manner in which the speeches were delivered is provided. This occurs,

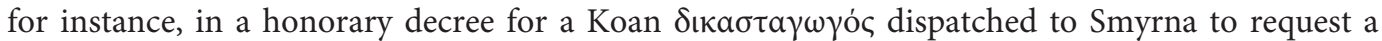
commission of foreign judges, showing that his oration before the council and the assembly to persuade the Smyrnaeans to send them was "detailed"28. As briefly pointed out above, the question as to whether the envoys' oratorical skills served as a complement to the written documentation and the supporting evidence brought by them (in general, civic decrees authorising the mission and outlining their instructions), and were consequently considered as instrumental in determining the successful outcome of diplomatic exchanges, has recently become the object of scholarly debate. In particular, by building extensively on the epigraphical evidence, Lene Rubinstein has attempted

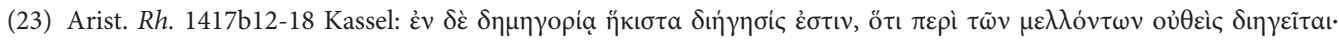

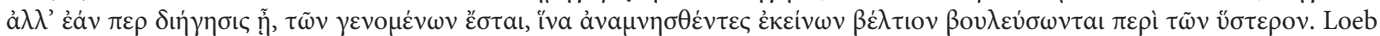
translation by J. H. Freese: "In deliberative oratory narrative is very rare, because no one can narrate things to come; but if there is narrative, it will be of things past, in order that, being reminded of them, the hearers may take better counsel about the future".



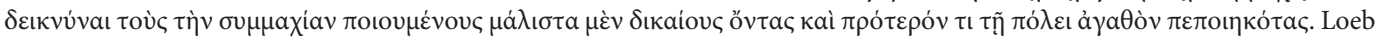
translation by D. C. Mirhady, slightly modified: "When you wish to argue for making an alliance, you must explain [...] that the allies are just and they have earlier done something good for the city".


precedente alleanza). An illuminating instance of this pattern is Callias' reference to Triptolemos' gift of Demeter's grain to the Peloponnese within the context of the Athenian peace embassy to Sparta in 371 BC (X. HG 6.3.6). On this, see recently Rubinstein 2016, esp. p. 103-105.

(26) See, however, the caveat of ERskine 2002, p. 98 regarding kinship and its role in Hellenistic diplomacy.

(27) On this point, see lastly Сналiотіs 2016, p. 129-134 (with special reference to the features of the so-called narratio

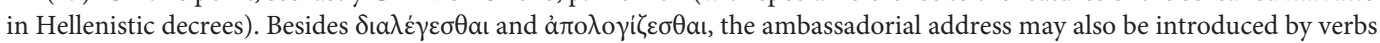



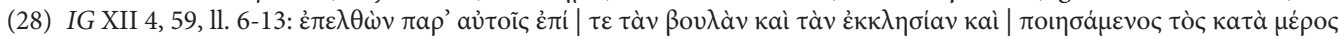
$\lambda$

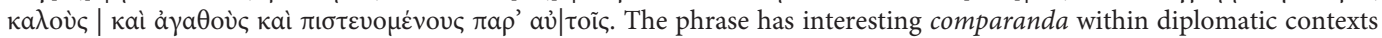

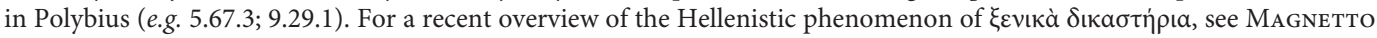
2016, p. 28-34. 
to investigate the extent to which the ambassadors' presentations impacted on the recipient communities and influenced their decision-making processes, further concluding that "the fact that the written material did not invariably replace the oral performance by envoys strongly suggests that priority continued to be given to oratory as a vital part of interstate communication" 29 . In what follows, my aim is to develop Rubinstein's work and provide further arguments in favour of her thesis by collecting some other instances of epigraphically attested ambassadorial addresses before kings and poleis.

Among the factors that point to the conclusion that envoy's speeches played a primary role in post-Classical diplomatic exchanges is the circumstance that Greek envoys utilised tailored oratorical strategies for their audiences. This is particularly evident when contrasting the different epigraphical responses given by poleis, confederations and kings that were visited during such major diplomatic campaigns as those promoted from the mid-third century BC onwards by Cos, Magnesia on the Maeander and Teos, as well as, to a lesser extent, by other communities throughout the Hellenistic world (for instance, Smyrna, Cyzicus and Cnidos), to obtain recognition


of such documents, which survive in epigraphical dossiers set up in crucial spots of the dispatching cities, leads to the conclusion that, depending on the audience, different aspects of the politics, history and mythology were emphasised on a case-by-case basis. This is clearly shown by the answers given to the Magnesian teams of roving $\theta \varepsilon \omega \rho$ oi by, among others, Epidamnus (I.Magnesia 46), Same on Cephallenia (I.Magnesia 35), Megalopolis (I.Magnesia 38) and Antiochia in Persis $(\text { I.Magnesia } 61)^{31}$, as well as by the responses that the two Teian $\pi \rho \varepsilon \dot{\sigma} \sigma \beta \varepsilon \varsigma$ Apollodotus and Colotas obtained within the framework of the first round of requests for the inviolability of the sanctuary of Dionysus ${ }^{32}$.

If, in general, the respondents hinted at the arguments of the ambassadors in a shorthand way despite the presentation of detailed cases, there remain nonetheless some civic decrees and royal letters in which their addresses are more or less carefully summarised and recounted in detail ${ }^{33}$. A notorious example is the much discussed dossier of documents discovered in 1965 during the excavations of the federal sanctuary of the Lycians, regarding an embassy from the city of Kytenion in Doris visiting Xanthos in 206/5 BC in which financial aid was requested for reconstructing the city wall after the damages caused by an earlier earthquake and a recent invasion by Antigonus Doson $^{34}$. It is not my intention here to readdress the numerous issues raised by this inscription, all

(29) Rubinstein 2013, esp. p. 168. Cf. KienASt 1973, cols. 559-560. On the combination of oral persuasion and written materials (including royal letters and civic decrees) as a characteristic of Hellenistic diplomatic exchanges, see also VIRGILIO 2013, p. 244-245 and, more recently, Ceccarelli 2018, esp. p. 175, who argues that one of the reasons why civic envoys had to comment on the documents that they conveyed is that, unlike a royal letter, "the decree is a singularly 'introverted' form of speaking". On the circulation of travelling decrees in the Hellenistic world, see the classic essay by Massar 2006.

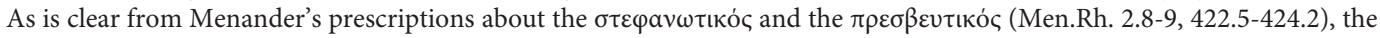
conveyance of $\psi \eta \varphi$ i $\sigma \mu \alpha \tau a$ was still a prominent feature of diplomatic undertakings in the Imperial period. On this, see also FERRARY 2016, p. 187.

(30) On ảou入ia, see now KNÄPPER 2018 (with all previous bibliography).

(31) On this point, see also Erskine 2002, p. 98-100; Chaniotis 2009, p. 263-264. For a thorough analysis of the innumerable issues connected with this dossier, see now Ceccarelli 2018.

(32) On the Teian dossier, see lastly Vinci 2008-2009.

(33) Cf. Kienast 1973, col. 561. It should, however, be borne in mind that, as rightly emphasised by Erskine 2007, p. 277, these documents usually "give us a listener's perspective on the speeches of the visiting ambassadors, shaping the report according to their own priorities".

(34) SEG XXXVIII 1476. Recent editions: Curty 1995, no. 75; Meier 2012, no. 69. Cf. Hadzis 1997; Jones 1999, p. 61-62, 139-143; LÜCKE 2000, p. 30-52; ERsKine 2002, p. 101-102; MA 2003, p. 7-11; PASCHIDIS 2008, p. 328-332 (C32-34); STAVRIANOPOULOU 2013b, p. 191-195; CHANIOTIS 2016, p. 131-132, 155-157, 159-161. 


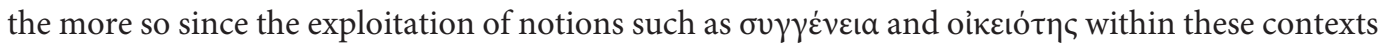
has received extensive scholarly treatment over the last few decades ${ }^{35}$. Still, I wish to draw attention to a point that seems to have so far escaped general consideration, namely how closely the oration by the Kytenian envoys, as is rephrased in the opening Xanthian decree, fits the template provided by Menander Rhetor for delivering a successful $\pi \rho \varepsilon \sigma \beta \varepsilon v \tau$ เкòৎ $\lambda$ ó $\gamma \circ \varsigma$, which, however, was meant to be performed in Imperial times ${ }^{36}$. For what Menander expounds as the second topos on which the prospective ambassador has to rely so as to be effective is nothing but a form of $\dot{\varepsilon} \lambda \varepsilon \varepsilon เ v 0 \lambda$ ojia, a category which has recently been recalled for characterising this speech ${ }^{37}$. This consideration applies to the $\pi$ pooi $\mu$ เov of the Kytenian address, which sets out the reasons behind the mission ${ }^{38}$, as well as to what appears to have been a sort of $\dot{\varepsilon} \pi i \lambda o \gamma o \varsigma$ following the mythological demonstration (at 1l. 30-42).

One of the most significant conclusions reached by Rubinstein in her study on the importance of ambassadorial addresses for Hellenistic inter-polis relations is that "the envoys' speeches often appear to have been intended as a means of perpetuating, rather than repaying, the debt of charis already owed by the envoys' home community to that of the addressees" ${ }^{39}$. In other words, the beneficiary's oral celebrations of the favours received from the benefactor in the past would have functioned as a sort of captatio benevolentiae and, therefore, as a way to obtain new favours or to ask support for present requests. An eloquent example of such is an interesting inscription within

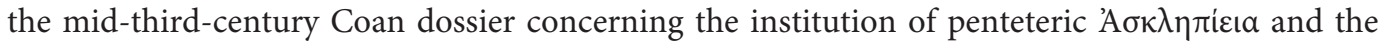
quest for obtaining the sanctuary's inviolability ${ }^{40}$, namely the response of the Bithynian king Ziaelas, son of Nicomedes I and father of Prusias I. As emerges from a comparison between his

(35) On this point, see recently, with further references to the abundant literature, Battistoni 2010; Patterson 2010,

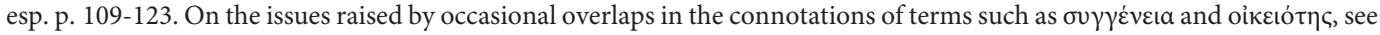
Musti 2001; SAmmartano 2007. The importance of kinship diplomacy in the post-Alexander world is further reflected in Hellenistic historiographical pratice, as revealed by Polybius' observations on the spreading of works focusing on mythical



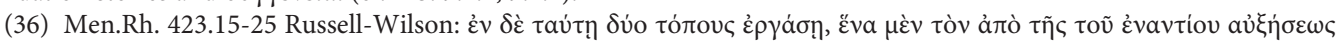

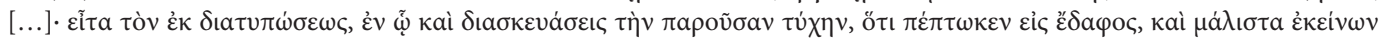



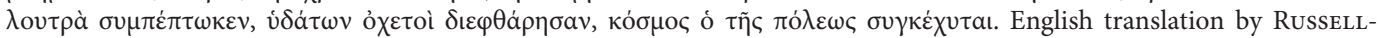
WiLson 1981, p. 181: "In this context, you should work up two topics. One is based on amplification of the contrary [...]. Pass next to the topic of vivid description, in which you should elaborate the present misfortune, how the city has fallen to the ground. You should mention in particular the things that contribute to utility and to life, for which emperors are used to taking thought, e.g. that the baths have fallen down, the aqueducts have been destroyed, the glory of the city is ruined". On Greek diplomacy in the Imperial period, see now Gordillo Hervás 2017.



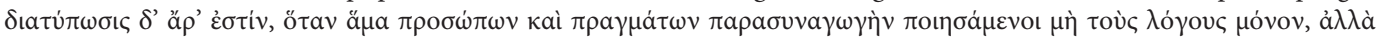

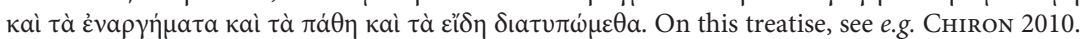

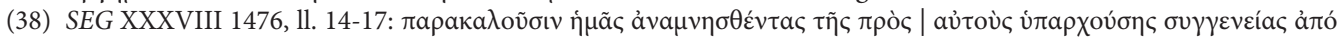

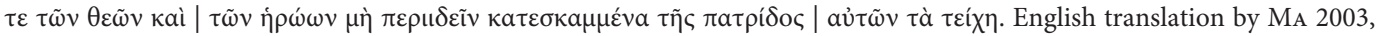
p. 8: "(the ambassadors) exhort us to remember our kinship-relations with them, that originate from the gods and heroes, and hence to refuse to tolerate that the walls of their homeland lie destroyed".

(39) Rubinstein 2013, p. 196-197. See, however, the discussion in Piccirilli 2002a, p.96-98 (8. Morale del contraccambio).

(40) IG XII 4, 209. Other editions: Syll. ${ }^{3} 456$; RC 25; Rigsby 1996, 11. On the historical background behind this diplomatic enterprise, see, for instance, BURASELIS 2004 (SEG LIV 735). For an analysis of the rhetorical strategies deployed by the Coan envoys, see Nelson 2005, NeLson 2013, who has also made the tempting suggestion that the historical proofs underlying their arguments possibly derived from the work of a local historian, Macareus of Cos (FGrHist 456), that could

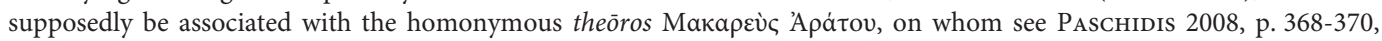


would be nothing but excerpts from Macareus' Kwaká and possibly connected with his involvement in the diplomatic grand tour. Unfortunately, P. Stronk at BNJ 456 fails to take this tantalising suggestion into account. 
answer and those given by other kings and cities $^{41}$, the envoys utilised in this case a tailored strategy by reminding the king of his father's good disposition ( $\varphi \imath \lambda \alpha v \theta \rho \omega \pi i \alpha)$ towards the Coans ${ }^{42}$, and, in an attempt to make their claim stronger and persuade him to comply with such a policy, a reference was probably made to the traditional ties between the island and Alexandria:

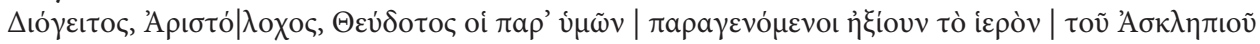

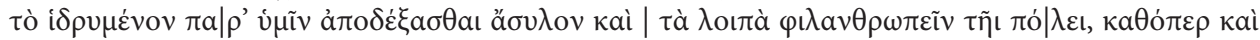

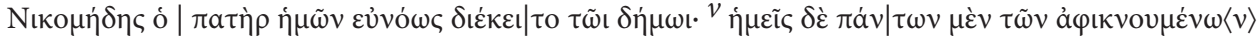

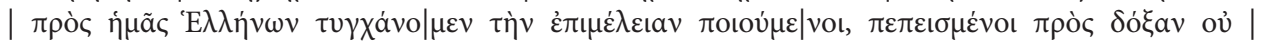

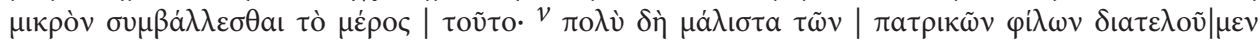

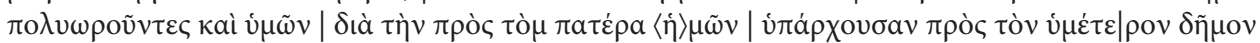

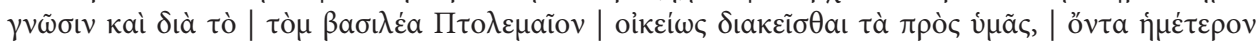
pì

Your envoys Diogeitus, Aristolochus, and Theudotus came and requested that the sanctuary of Asclepius which is established in your city should be accepted by us as inviolate and that in other respects we should favour your city, just as Nicomedes our father was well disposed to your people. We actually show care for all the Greeks who come to our country, as we are convinced that this makes no small contribution to our good reputation. In particular we continue to show high regard for our father's 'friends' and for you, because of our father's acquaintance with your people, because King Ptolemy (III) is well disposed towards you (and he is our friend and ally), and also because your envoys recounted with great enthusiasm the goodwill which you have for us ${ }^{43}$.

If one considers that the respondents usually took up issues which were first addressed by the envoys, there can be little doubt that the reference to Ptolemy III occurred already in the ambassadorial address despite Antigonus Gonatas' recent victory in the sea fight off Cos (somewhere between 262 and $256 \mathrm{BC})^{44}$. The Coan envoys seem to have adopted a similar oratorical strategy while addressing an unknown king, possibly identified-according to the Roberts' illuminating suggestion - with a member of the Spartocid dynasty (perhaps Paerisades II), despite the fact that on that occasion their set speech was based on kinship arguments:

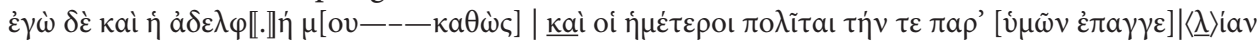

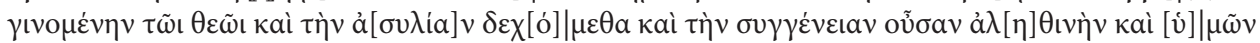

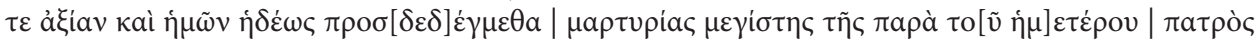

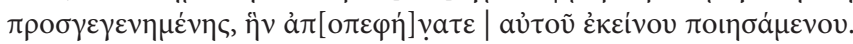

I and my sister [...] and our citizens accept both your [proclamation] that has been made for the god and the inviolability, and we also have accepted gladly the kinship as true and worthy of you and us, the best testimony being that of our father, which you have made clear he himself furnished ${ }^{45}$.

If, as I suspect, the Roberts' hypothesis is correct, one might easily think of Panticapaeum as one of

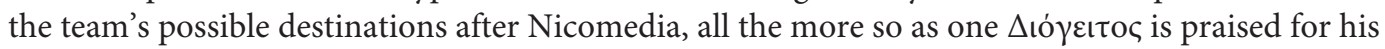

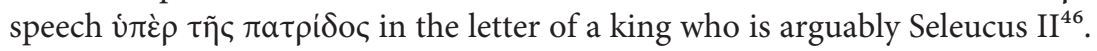

(41) On Ziaelas and the Bithynian monarchy, see especially Michels 2009, p. 56-65.

(42) On $\varphi \iota \lambda \alpha v \theta \rho \omega \pi i$ in Hellenistic inscriptions and historians, see recently GraY 2013.

(43) IG XII 4, 209, 11. 3-26. English translation by Austin 2006², p. 140.

(44) Cf. e.g. Erskine 2013, p. 357, who argues that "[t]he Koans, by approaching a king somewhat on the margins of the Greek world, were recognising his desire to participate in the community of Greeks".

(45) IG XII 4, 213, ll. 20-27. English translation by K. J. Rigsby. Cf. CURTy 1995, p. 48-49, no. 24e; LüCKe 2000, p. 133.

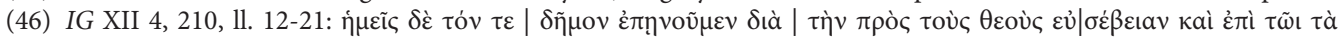

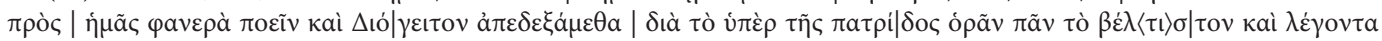
кaì $\pi \rho \alpha \dot{\tau} \mid \tau o v \tau \alpha$. English translation by C. Bradford Welles: "We praised your people because they reverenced the gods and made clear their feelings toward us, and we approved Diogitus because in both word and deed he saw what was in all cases best for the city". This is one of the rarest cases that provide close insight into what was actually said not by the team on the 
The second instance that I would like to add to Rubinstein's collection of epigraphic materials is a letter of the 270s or 260s with which one Antiochus responded to the honours sent to him by the

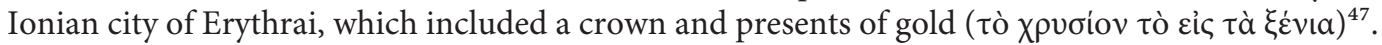
The decree authorising the embassy probably emanated from the newly restored democratic government, which, according to Teegarden's reconstruction ${ }^{48}$, was refounded in Erythrai after the battle of Kouroupedion (281 BC). The king's detailed response offers several clues for reconstructing the essence of the envoys' speech, which, besides conventionally recalling the goodwill (Evvvoia) and

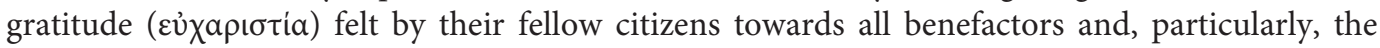
Seleucid house, addressed the issue of Erythrai's political status and pre-eminence ( $\pi \rho \circ \gamma \omega \gamma \eta \dot{)})$ in the past so as to persuade the king to support their request:

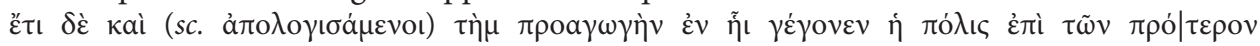

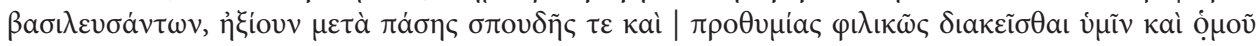

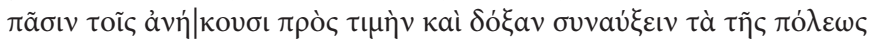

and they themselves spoke [...] also about the eminent position enjoyed by the city under the former kings, and they requested with every earnestness and zeal that we should be well disposed to you and that at the same time we should help in increasing the city's privileges in all that relates to honour and glory ${ }^{49}$.

Yet Antiochus does not limit himself to providing this brief summary. He also states that the decision to follow in the footsteps of his predecessors by consenting to the request that Erythrai be accorded autonomy and exemption from taxation was deeply influenced, among other things, by the envoys' oral performance ${ }^{50}$. Whatever the absence of Lysimachus, who had ruled the city in the early third century, in the ambassadorial address may imply, Antiochus' rephrasing reveals that, by oi $\pi \rho$ ó $\varepsilon \rho o v ~ \beta a \sigma i \lambda \varepsilon v ́ \sigma \alpha v \tau \varepsilon \varsigma$, the envoys meant both Alexander, who restored democracy in the cities of Asia Minor (Arr. An. 1.18.1-2), and Antigonus Monophthalmus ${ }^{51}$, and not the Persian domination after the King's Peace (386 BC):

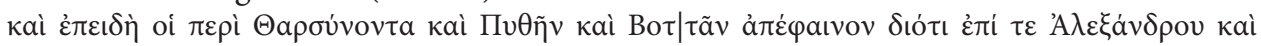

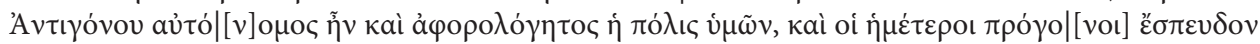

whole, but by one of its components (on this point, see also KiENAST 1973, cols. 542, 561). However, I am not as convinced

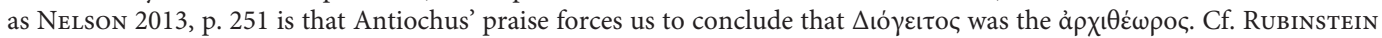
2013, p. 184: "The number of envoys sent out on a single mission could be anything between one and ten (and in a few instances even more), each of whom probably contributed his own speech".

(47) I.Erythrai 31. Other editions: OGIS 223; RC 15; Kotsidu 2000, no. 237 (E2). Cf. e.g. Giovannini 2007, p. 77; Bencivenni 2010, p. 156, n. 27; Grainger 2014, ch. 11, n. 29; Teegarden 2014, p. 160. The honorific decree conveyed by the Erythraian envoys is I.Erythrai 30. H. Engelmann and R. Merkelbach tentatively suggest that such honours be bestowed upon the newly crowned Antiochos II, yet this assumption seems to be contradicted by the parallelism between $\dot{\varepsilon} v$ ả $\rho \chi \tilde{\eta} ا$

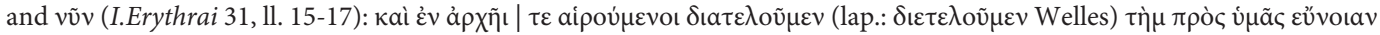

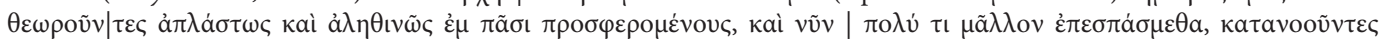

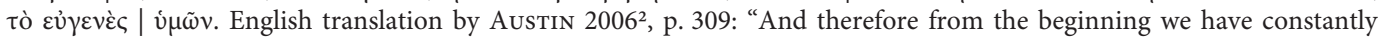
maintained our goodwill towards you, as we can see the sincerity and honesty of your conduct, and now we are even more attracted to you, as we recognise your nobility". On the role played by such 'presents' of gold in ancient Greek diplomacy, see e.g. KiEnAST 1973, cols. 569-570.

(48) Teegarden 2014, esp. p. 162.

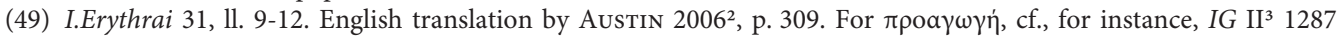
(185/4 BC), 1. 10; Plb. 15.34.5; D.S. 18.62.3.

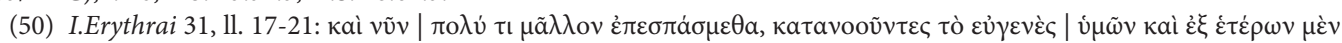

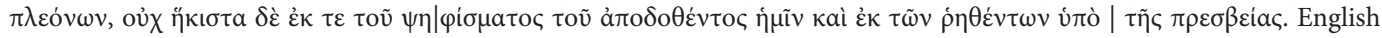
translation by AUsTin $2006^{2}$, p. 309: "and now we are even more attracted to you, as we recognise your nobility from many other proofs, and not least from the decree which was handed over to us and from the words spoken by your ambassadors".

(51) On the restoration of democracy in the cities of Asia Minor by Alexander, see now WALlace 2018, esp. p. 63-70 (a brief discussion of I.Erythrai 31 is at p. 65). On Antigonus Monophthalmus' policy of freedom and autonomy for the Greeks, see, e.g., Billows 1990, esp. p. 189-236; Сhampion 2014, p. 187-195. 


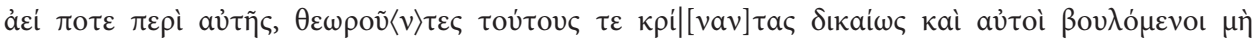

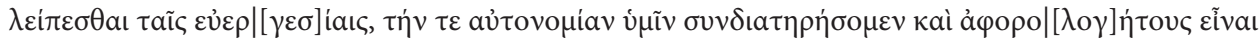

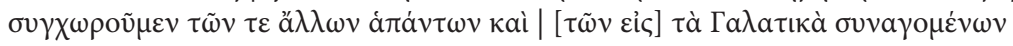

And since Tharsynon, Pythes and Bottas declared that under Alexander and Antigonus (the OneEyed) your city was autonomous and free from tribute, and our ancestors were constantly zealous on its behalf, and since we see that their decision was just and we ourselves wish not to fall short in (our) benefactions, we shall help to preserve your autonomy and we grant you exemption from tribute, including all the other taxes and [the] contributions [to] the Gallic fund ${ }^{52}$.

It is worth emphasising that the reference to the king's ancestors and their regard, far from being an indisputable chronological element for seeing in the sender Antiochus II (instead of his father $)^{53}$, sounds odd as an argument in the mouth of the citizen of a polis that in the summer of 314 $\mathrm{BC}$, at the time when its walls were under construction, was attacked by Seleucus, in the capacity of commander-in-chief of Ptolemy's forces ${ }^{54}$. At any rate, a striking feature of the discursive protocol of the Erythraian envoys before Antiochus is the deployment of historical demonstrations for exhortative purposes, a rhetorical device that finds close parallels not only in the arguments found in Polybius' speeches, but also in those advanced in Hellenistic territorial disputes (whose purpose

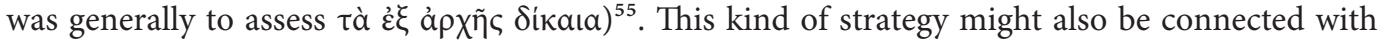
that utilised by envoys on diplomatic tours, who referred to the positive responses already received, as well as to recent and remote benefactions, to support their case before the communities still to be visited ${ }^{56}$. Angelos Chaniotis has argued that such positive answers should be interpreted, in

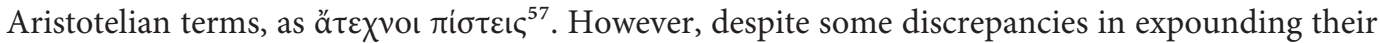
respective theories of rhetorical proofs, especially as regards Aristotle's introduction of logicodialectical notions such as 'induction' ( $\dot{\pi} \pi \alpha \omega \gamma \eta \dot{n})$ into the field of $\dot{\rho} \eta \tau \rho \rho \kappa \eta^{58}$, both the Rhetoric and the Rhetoric to Alexander do agree that these ways of exploiting the past are to be seen as

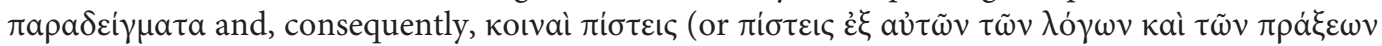
кaì $\tau \tilde{\omega} v \dot{\alpha} v \theta \rho \omega \dot{\omega} \pi \omega v)$, namely arguments whose main purpose is that of pointing to similarities ${ }^{59}$. It

(52) I.Erythrai 31, 11. 21-28. English translation by Austin $2006^{2}$, p. 309. For a discussion on the identity of the king, see especially НАвісHт $1970^{2}$, p. 93-99; KoeHn 2007, p. 120-121.

(53) As first argued by Rostovtzeff 1935.

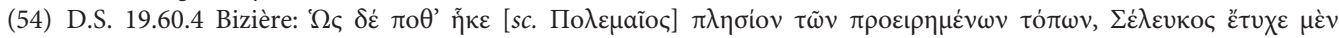
$\pi$ о R. M. Geer: "It so happened that, as he finally drew near to this area, Seleucus was laying siege to Erythrae, but when he heard that the hostile force was near, he sailed away with noting accomplished".

(55) On this kind of pattern, see especially MAGNETTO 2008, with particular reference to the Rhodian arbitration between Samos and Priene, which provides a meaningful illustration.

(56) The same seems applies to the Coan dossier, as is clear from the letter of Ptolemy III summarising the speech held

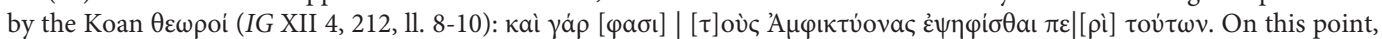
cf. Nelson 2005, p. 220.

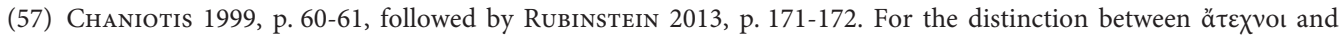

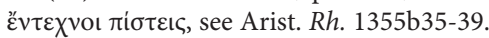

(58) On this point, see, for instance, Piazza 2011.

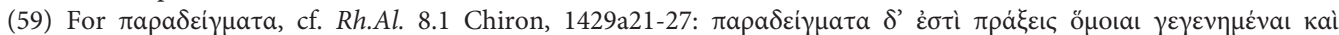

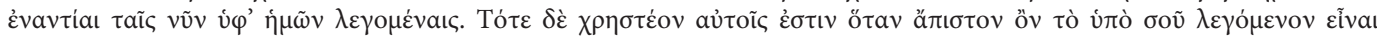

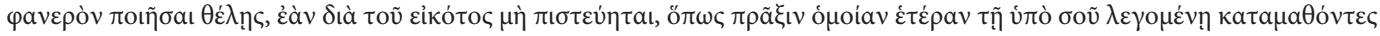

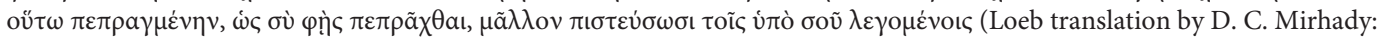
"Examples are actions that have taken place that are similar or contrary to those being discussed by us now. You must use them whenever what you are saying is hard to believe but you want to make clear (if it does not become credible through an argument from plausibility) that once they learn that an action similar to the one being discussed by you has been done as

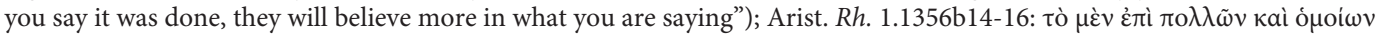

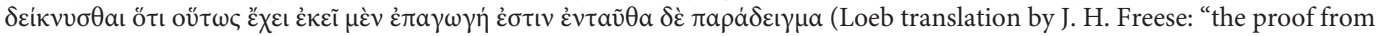
a number of particular cases that such is the rule, is called in Dialectic induction, in Rhetoric example"). 
is probably no coincidence that most instances of $\pi \alpha \rho \alpha \delta \varepsilon i \gamma \mu \alpha \tau \alpha$ referred to in both treatises stem from Greek history, so that in the Rhetoric to Alexander the following advice is given: $\pi \mathrm{o} \lambda \lambda \dot{\alpha} \delta \dot{\varepsilon}$

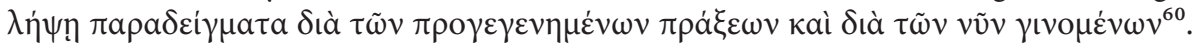

The last example on which I intend to focus is the Delphian decree in honour of the ambassador and $\theta \varepsilon о \pi \rho \dot{\pi} \pi$ ऽ Matrophanes (namely a sacred envoy sent forth on an oracular mission) ${ }^{61}$, who was dispatched by Sardis to renew the $\varphi \iota \lambda \alpha \dot{\alpha} \theta \rho \omega \pi \alpha$ existing between the two cities $\dot{\varepsilon} \kappa \pi \alpha \lambda \alpha i \tilde{\omega} \nu$ $\chi \rho o$ o $\omega v-$ an indication that almost surely refers to the notorious relationship between the Lydian king Croesus and the sanctuary of Apollo ${ }^{62}$. The inscription is probably to be dated to the last quarter of the third century $\mathrm{BC},{ }^{63}$ coinciding with the last phase of the long Aetolian predominance over Delphi and the Amphictyonic League, which was brought to an end by the defeat of Antiochus III and his allies by Rome. This can be inferred from the fact that the honours bestowed on the envoy and his descendants (at 1l. 14-17) included the $\theta \varepsilon \omega \rho o \delta$ okia for the Aetolian $\sum \omega \tau$ in was formally granted the status of polis around $226 \mathrm{BC}$. From the summary provided in the decree, it emerges that Matrophanes' oration had two main aims: on the one hand, to explain the reasons why the Sardians had long been unable to approach the oracle; on the other, to ask the Delphians

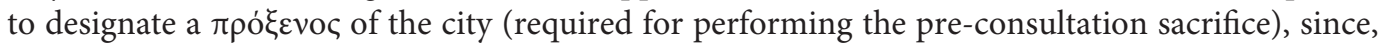
for the same reasons, there was none at Delphi at that time. In response to this request, the polis of Delphi decided to act as a $\pi \rho \xi_{\varepsilon} \varepsilon v o \varsigma$ of the polis of Sardis-a provision whose interpretation has elicited much discussion among scholars-and, consequently, to enable Matrophanes to access the oracle after the $\pi \rho 0 \theta v \sigma i \alpha$ :

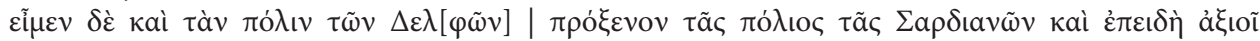

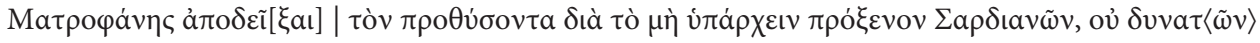

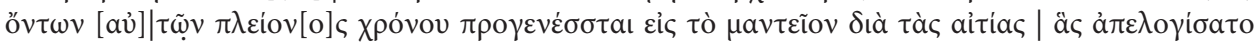

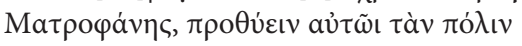

The city of the Del[phians] is to be proxenos of the city of the Sardians, and, seeing that Matrophanes asks that we app[oint] someone who will carry out the preliminary sacrifice, since the Sardians have no proxenos, they being unable to approach the oracle for a long period for the reasons [- - ] that Matrophanes set out, the city will carry out the preliminary sacrifice for him ${ }^{64}$.

Curiously enough, although it can safely be assumed that the task of demanding the designation of a new $\pi \rho$ ó $\varepsilon v 0 \varsigma$ was already outlined in the decree of appointment enacted by the Sardians (in addition to that of justifying their absence from the oracle), it is the envoy whom the Delphians held responsible for this request.

(60) In the section concerning the confirmation through proofs ( $\beta \varepsilon \beta a i \omega \sigma \iota \varsigma, ~ \varepsilon ̇ \kappa ~ \tau \tilde{\omega} v \pi i \sigma \tau \varepsilon \omega v)$ the author claims that the best examples are those close to the audience in time or place (Rh.Al. 32.3 Chiron, 1439a1-4).

(61) JACQUemin et al. 2012, no. 83, p. 163-165. Other recent editions: Rutherford 2013, p. 416-418, no. D14. In addition to the references given in the Choix, one should add at least KRAUTER 2004, p. 86-88; ZelniCK-Abramovitz 2004, p. 103-104; Taita 2004-2005, p. 95-98; Arnush 2005, p. 108; Mack 2015, p. 25 n. 9, p. 69 n. 57. On Hellenistic Sardis, see now BERLIN-Kosmin 2019 [non vidi].

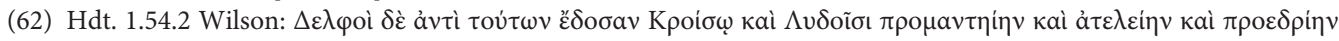

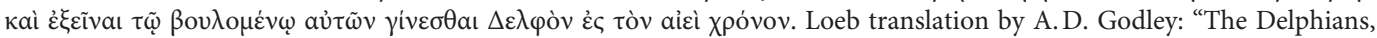
in return, gave Croesus and all Lydians the right of first consulting the oracle, freedom from all charges, the chief seats at festivals, and perpetual right of Delphian citizenship to whosoever should wish".

(63) Cf. Gauthier 1989, p. 143-150 (226-225 BC); KNoepfler 1993, p. 39-43 (213/2 BC).

(64) Pouilloux 1974, 11. 9-13 (see also JACquemin et alii 2012, no. 83). English translation by Rutherford 2013,

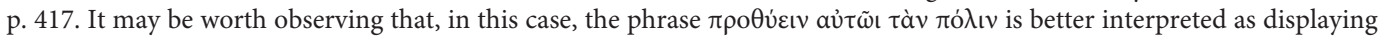
both of the traditional meanings of the preposition $\pi \rho$, namely "before" and "on behalf of". 
4. In examining the formal features of some of the inscriptions recalled above, including the Xanthian dossier, Laurent Pernot raised an important point:

Les documents cités présentent une remarquable homogénéité de style. Ils utilisent le même vocabulaire, les mêmes structures syntaxiques, et ont quelque chose de vaguement isocratique. C'est un style qui rend un son encomiastique autant que délibératif, d'ailleurs ${ }^{65}$.

It should therefore come as no surprise that, as stated above, the $\pi \rho \varepsilon \sigma \beta \varepsilon v \tau$ เ imperial period among the epideictic forms, which points to a shift that had already taken place in oratorical practice and that is clearly visible, for instance, in the mythological argumentations deployed in a number of epigraphically attested ambassadorial addresses ${ }^{66}$. Nor is it surprising that, by combining exhortation and advice to epideictic elements, the $\pi \rho \varepsilon \sigma \beta \varepsilon v \tau$ associated with the $\pi a v \eta \gamma v \rho ı$ ó, at least by rhetoricians (and from a theoretical standpoint) ${ }^{67}$. After all, by juxtaposing arguments based on historical proofs and previous benefactions, as well as discussions of recent and contemporary history, Hellenistic envoys were adopting a rhetorical pattern which had been established in epideictic oratory at least since Lysias' 'O $\lambda v \mu \pi$ ikóc, with its initial tribute to Heracles' $\varepsilon \dot{\varepsilon} \rho \gamma \varepsilon \tau \dot{\eta} \mu \alpha \tau \alpha^{68}$. On the other hand, it cannot be denied that the arguments deployed within the context of interstate mediations and arbitrations, despite also at times being based on historical proofs emanated from the remote past ${ }^{69}$, were most likely driven from the repertoire of forensic oratory, which, in turn, had undergone a theoretical revolution due to Hermagoras' systematisation.

Regardless of whether the compresence of two different temporal dimensions within such oratorical performances actually corresponds, as Chaniotis puts it, to "a distinction between collective and cultural memory," ${ }^{\prime 70}$ which would imply that Hellenistic envoys' speeches could be better understood as a further manifestation of Gehrke's concept of intentionale Geschichte (in other words, as means of self-assertion through multifaceted processes of memory making) ${ }^{71}$, what is at stake here is the problem of determining if, as argued by Rubinstein, Polybius' classification

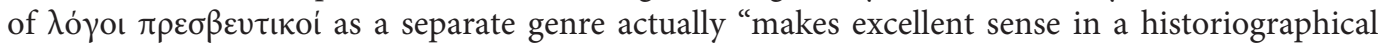
universe, but less sense when applied to oratory as it may have been performed in real life". The answer should, in my view, take into account the fact that, in order for it to be suitable for all of the contexts delineated above, the ambassadorial address was forced to overthrow its original

(65) Edwards 2016, p. 181 (within the discussion following the paper by CHANiotis 2016).

(66) There is another reason that makes the Coan dossier so interesting a case for the present argument. If Nelson's assumption be accepted (see above, n. 40), the rhetorical strategy of combining moral obligations and alleged historical demonstrations in Hellenistic diplomatic approaches would find a further comparandum in the pseudo-Hippocratic Ambassadorial Speech (27.9 Smith) in which Hippocrates' son Thessalos exhorts the Athenians to spare his homeland on account not only of the other benefactions towards the Greeks referred to in the oration, but also of those performed by the

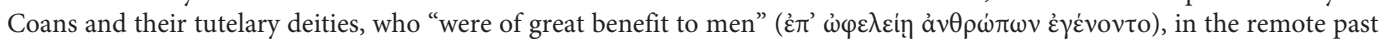

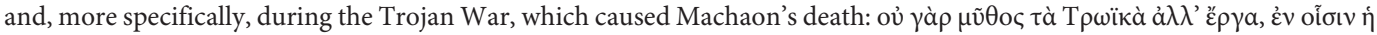

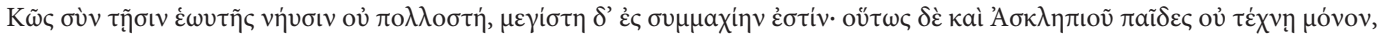

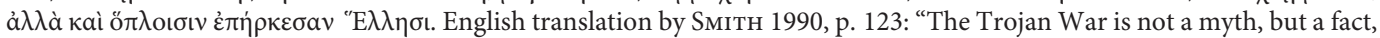
and in it Cos with her own ships was not quantitatively great but was very great for the alliance. And thus Asclepius' sons helped the Greeks not by science alone, but by arms".

(67) On this point, see PEPE 2013, esp. p. 330-331.

(68) Lys. 33.1-2 Carey (apud D.H. Lys. 30).

(69) As the already mentioned case of the Rhodian arbitration between Samos and Priene clearly reveals (see above, n. 55). On the "tendency towards the mixture of forensic and ambassadors' speeches" in the Hellenistic period, see Thornton 2013, p. 26-27. See further Rubinstein 2016, p. 80.

(70) Chaniotis 2009, esp. p. 255-259.

(71) Ma 2003, p. 19: "the speeches given by ambassadors, foreign judges and theoroi must be considered as part of local civic literature". On the Horographie as a means to (re)construct civic identity in the Hellenistic period, see lastly SimONTON 2018, esp. p. 507-508, notes 53-55 (with exhaustive references). 
symbouleutic nature so as to incorporate, combine and develop arguments of any kind, however still mostly historical and genealogical, epideictic and ceremonial, ritual and religious, legal and moral. In addressing its emergence as an issue, Demetrius, Polybius and Diodorus were thus not so much adopting a descriptive coinage from a merely historiographical perspective, they were rather dismissing the applicability of a scheme whose practical validity had inevitably been questioned by the radical changes determined by the new political realities of the Hellenistic age.

Davide Amendola Scuola Normale Superiore di Pisa, Center for Hellenic Studies, Harvard University davide.amendola@sns.it

\section{Bibliography}

Adcock, F. J., Mosley, D. J., 1975, Diplomacy in Classical Greece, London.

Arnush, M., 2005, "Pilgrimage to the Oracle of Apollo at Delphi: Patterns of Public and Private Consultation", in J. Elsner, I. Rutherford (eds.), Pilgrimage in Graeco-Roman and Early Christian Antiquity: Seeing the Gods, Oxford, p. 97-110.

Austin, M., 2006, The Hellenistic World from Alexander to the Roman Conquest: A Selection of Ancient Sources in Translation, Cambridge (2nd edition).

Battistoni, F., 2010, Parenti dei Romani. Mito troiano e diplomazia, Bari.

Bencivenni, A., 2010, "Il re scrive, la città iscrive. La pubblicazione su pietra delle epistole regie nell'Asia ellenistica”, Studi Ellenistici 24, p. 149-178.

Berlin, A. M., Kosmin, P.J., 2019, (eds.), Spear-Won Land: Sardis from the King's Peace to the Peace of Apamea, Madison, WI.

Billows, R. A., 1990, Antigonos the One-Eyed and the Creation of the Hellenistic State, Berkeley et al.

Börm, H., Luraghi, N., 2018, (eds.), The Polis in the Hellenistic World, Stuttgart.

Buraselis, K., 2004, "Some Remarks on the Koan Asylia (242 B.C.) against its International Background", in K. Höghammar (ed.), The Hellenistic Polis of Kos: State, Economy and Culture, Uppsala, p. 15-20.

Buraselis, K., 2018, "A Royal Peace: The Hellenistic King and his Officials as Mediators/Arbitrators and

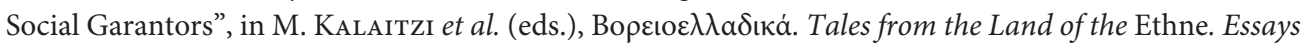
in honour of Miltiades B. Hatzopoulos, Athens, p. 253-264.

Burton, P. J., 2011, Friendship and Empire: Roman Diplomacy and Imperialism in the Middle Republic (353146 BC), Cambridge.

Ceccarelli, P., 2018, "Letters and Decrees: Diplomatic Protocols in the Hellenistic Period", in P. Ceccarelli et al. (eds.), Letters and Communities: Studies in the Socio-Political Dimensions of Ancient Epistolography, Oxford, p. 147-183.

Champion, J., 2014, Antigonus the One-Eyed: Greatest of the Successors, Barnsley.

Сналіотіs, A., 1999, "Empfängerformular und Urkundenfälschung: Bemerkungen zum Urkunden-dossier von Magnesia am Mäander", in R. G. KHOuRY (ed.), Urkunden und Urkundenformulare im klassischen Altertum und in den orientalischen Kulturen, Heidelberg, p. 51-69.

Chaniotis, A., 2009, “Travelling Memories in the Hellenistic World", in R. Hunter, I. Rutherford (eds.), Wandering Poets in Ancient Greek Culture: Travel, Locality and Pan-Hellenism, Cambridge, p. 249-269. 
Chaniotis, A., 2013a, "Paradoxon, Enargeia, Empathy: Hellenistic Decrees and Hellenistic Oratory", in Kremmydas-Tempest 2013, p. 201-216.

Chaniotis, A., 2013b, "Emotional Language in Hellenistic Decrees and Hellenistic Histories", in MariThornton 2013, p. 339-352.

Chaniotis, A., 2016, "History as an Argument in Hellenistic Oratory: The Evidence of Hellenistic Decrees", in EDWARDs 2016, p. 129-174.

Chiron, P., 2010, "Citations et doctrine rhétorique dans le De figuris d'Alexandros", in L.CALboli Montefusco (ed.), Papers on Rhetoric X, Roma, p. 89-104.

Curty, O., 1995, Les parentés légendaires entre cités grecques, Genève.

Daubner, F., 2018, "Peer Polity Interaction in Hellenistic Northern Greece: Theoroi going to Epirus and Macedonia”, in Börm-Luraghi 2018, p. 131-158.

Dmitriev, S., 2011, The Greek Slogan of Freedom and Early Roman Politics in Greece, Oxford.

Dreyer, B., 2002, "Die Thrasykrates-Rede bei Polybios (11, 4-6) und die Bezeichnung der "Opfer“ im römisch-aitolischen Vertrag von 212 v. Chr.”, ZPE 140, p. 33-39.

Eckstein, A. M., 2006, Mediterranean Anarchy, Interstate War, and the Rise of Rome, Berkeley et al.

Eckstein, A.M., 2008, Rome Enters the Greek East: From Anarchy to Hierarchy in the Hellenistic Mediterranean, 230-170 BC, Malden, MA.

EDWARds, M., 2016, (ed.), La rhétorique du pouvoir. Une exploration de l'art oratoire délibératif grec, Vandœuvres.

EILERs, C., 2009, (ed.), Diplomats and Diplomacy in the Roman World, Leiden-Boston.

Erskine, A., 2002, "O Brother, Where are Thou? Tales of Kinship and Diplomacy", in D. Ogden (ed.), The Hellenistic World: New Perspectives, London, p. 97-115.

Erskine, A., 2007, "Rhetoric and Persuasion in the Hellenistic World: Speaking up for the Polis", in I. Worthington (ed.), A Companion to Greek Rhetoric, Malden, MA, p. 272-285.

Erskine, A., 2013, “The View from the Old World: Contemporary Perspectives on Hellenistic Culture", in StAVRianopoulou 2013a, p. 339-363.

Erskine, A., Llewellyn-Jones, L., Wallace, S., 2017, (eds.), The Hellenistic Court: Monarchic Power and Elite Society from Alexander to Cleopatra, Swansea.

Ferrary, J.-L., 2016, "Les Grecs devant le Sénat romain”, in EdwARds 2016, p. 183-201 (repr. as "La rhétorique des ambassadeurs grecs devant le Sénat romain” in Rome et le monde grec. Choix d'écrits, eds. J.-L.Ferrary, D. Rousset, Paris 2017, p. 241-254).

Forster, F. R., 2018, Die Polis im Wandel. Ehrendekrete für eigene Bürger im Kontext der hellenistischen Polisgesellschaft, Göttingen.

FröHlich, P., 2004, Les cités grecques et le contrôle des magistrats (IV ${ }^{e}-I^{e r}$ s. av. J.-C.), Genève.

Gauthier, Ph., 1989, Nouvelles inscriptions de Sardes II, Genève.

Giovannini, A., 2007, Les relations entre États dans la Grèce antique du temps d'Homère à l'intervention romaine (ca. 700-200 av. J.-C.), Stuttgart.

Gordillo Hervás, R., 2017, “Talking with the Emperor: Diplomacy and Language between Greece and Rome”, G\&R 64, p. 168-181.

Grainger, J.D., 2014, The Rise of the Seleukid Empire 323-223 BC: Seleukos I to Seleukos III, Barnsley.

Grainger, J.D., 2017, Great Power Diplomacy in the Hellenistic World, London-New York.

Grass, B., Stouder, G., 2015, (eds.), La diplomatie romaine sous la République. Réflexions sur une pratique, Besançon.

Gray, B. D., 2013, “The Polis Becomes Humane? $\Phi_{\imath} \lambda \alpha \nu \theta \rho \omega \pi i \alpha$ as a Cardinal Civic Virtue in Later Hellenistic Honorific Epigraphy and Historiography", in MARI-Thornton 2013, p. 137-162.

НАвіснт, С., 1970², Gottmenschentum und griechische Städte, München. 
Hadzis, C.D., 1997, “Corinthiens, Lyciens, Doriens et Cariens: Aoreis à Corinthe, Aoroi à Corcyre, Aor fils de Chrysaôr et Alétès fils d'Hippotès”, BCH 121, p. 1-14.

Hamon, P., 2005, "Le Conseil et la participation des citoyens: les mutations de la basse époque hellénistique", in P. Fröhlich, C. Müller (eds.), Citoyenneté et participation à la basse époque hellénistique, Genève, p. 121-144.

Jacquemin, A. et alii, 2012, Choix d'inscriptions de Delphes, traduites et commentées, Athènes.

Jones, C.P., 1999, Kinship Diplomacy in the Ancient World, Cambridge, MA-London.

KienAst, D., 1973, "Presbeia”, in RE, Suppl. XIII, cols. 499-628.

KLOSE, P., 1972, Die völkerrechtliche Ordnung der hellenistischen Staatenwelt in der Zeit von 280-168 v. Chr., München.

KnÄpper, K., 2018, Hieros kai asylos. Territoriale Asylie im Hellenismus in ihrem historischen Kontext, Stuttgart.

Knoepfler, D., 1993, "Le temple du Métrôon de Sardes et ses inscriptions”, MH 50, p. 26-43.

Koенn, C., 2007, Krieg-Diplomatie-Ideologie. Zur Außenpolitik hellenistischer Mittelstaaten, Stuttgart.

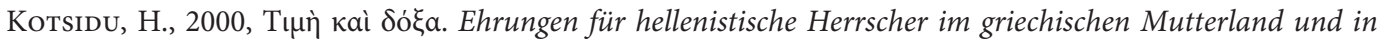
Kleinasien unter besonderer Berücksichtigung der archäologischen Denkmäler, Berlin.

Kralli, I., 2017, The Hellenistic Peloponnese: Interstate Relations. A Narrative and Analytic History, from the Fourth Century to 146 BC, Swansea.

Krauter, S., 2004, Bürgerrecht und Kultteilnahme. Politische und kultische Rechte und Pflichten in griechischen Poleis, Rom und antikem Judentum, Berlin-New York.

Kremmydas, C., Tempest, K., 2013, (eds.), Hellenistic Oratory: Continuity and Change, Oxford.

Low, P., 2007, Interstate Relations in Classical Greece: Morality and Power, Cambridge.

LÜCKE, S., 2000, Syngeneia. Epigraphisch-historische Studien zu einem Phänomen der antiken griechischen Diplomatie, Frankfurt am Main.

MA, J., 2003, "Peer Polity Interaction in the Hellenistic Age”, P\&P 180, p. 9-39.

Mack, W., 2015, Proxeny and Polis: Institutional Networks in the Ancient Greek World, Oxford.

Magnetto, A., 1997, Gli arbitrati interstatali greci, II: Dal 337 al 196 a.C., Pisa.

Magnetto, A., 2008, L'arbitrato di Rodi fra Samo e Priene, Pisa.

Magnetto, A., 2016, "Interstate Arbitrations and Foreign Judges”, in E. M. Harris, M. Canevaro (eds.), The Oxford Handbook of Ancient Greek Law, Oxford.

Magnetto, A., 2019, "I rapporti tra i diversi soggetti politici (stati territoriali, ethne, koina, città) e la diplomazia internazionale”, in M. MARI (ed.), L'età ellenistica. Società, politica, cultura, Roma, p. 75-100.

Mann, C., Scholz, P., 2012, (eds.), „Demokratie“ im Hellenismus. Von der Herrschaft des Volkes zur Herrschaft der Honoratioren?, Mainz.

Mari, M., Thornton, J., 2013, (eds.), Parole in movimento. Linguaggio politico e lessico storiografico nel mondo ellenistico, Pisa-Roma.

Martínez Morcillo, J.A., 2016, "La diplomatie dans les contextes de deditio en Grèce (200-167 av. J.-C.)", Ktèma 41, p. 211-222.

Massar, N., 2006, "La circulation des décrets dans les cités et entre cités à l'époque hellénistique", in L.Capdetrey, J. Nelis-Clément (eds.), la circulation de l’information dans les états antiques, Bordeaux, p. 73-87.

MeIer, L., 2012, Die Finanzierung öffentlicher Bauten in der hellenistischen Polis, Mainz.

Michels, C., 2009, Kulturtransfer und monarchischer Philhellenismus. Bithynien, Pontos und Kappadokien in hellenistischer Zeit, Göttingen.

Momigliano, A., 1940 [= 1992], "Liberty and Peace in the Ancient World", in A. Momigliano, Nono contributo alla storia degli studi classici e del mondo antico, ed. R. Di DonAto, Roma, p. 483-502.

Mosley, D. J., 1973, Envoys and Diplomacy in Ancient Greece, Wiesbaden. 
Musti, D., 2001, “La syngheneia e la oikeiotes: sinonimi o nuances?”, in M. G. Angeli Bertinelli, L. Piccirilli (eds.), Linguaggio e terminologia diplomatica dall'Antico Oriente all'Impero Bizantino, Roma, p. 43-63.

Nelson, E.D., 2005, "Coan Promotions and the Authorship of the Presbeutikos", in P. VAn DER EIJK (ed.). Hippocrates in Context, Leiden-Boston, p. 209-236.

Nelson, E.D., 2007, "Hippocrates, Heraclids, and the "Kings of the Heracleidai": Adaptations of Asclepiad History by the Author of the Presbeutikos", Phoenix 61, p. 234-246.

Nelson, E.D., 2013, “Coan Asylia: Small-State Diplomacy and the Hippocratic Legend”, in F. De Angelis (ed.), Regionalism and Globalism in Antiquity, Leuven et al., p. 247-266.

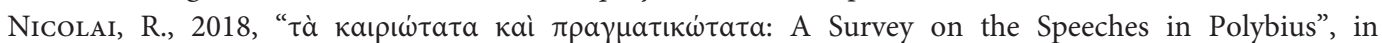
N. Miltsios, M. Tamiolaki (eds.), Polybius and his Legacy, Berlin-Boston, p. 117-130.

Oliver, G. J., 2006, "History and Rhetoric", in G. R. Bugh (ed.), The Cambridge Companion to the Hellenistic World, Cambridge, p. 113-135.

Olshausen, E., 1974, Prosopographie der hellenistischen Königsgesandten, I-II, Louvain.

Paschidis, P., 2008, Between City and King: Prosopographical Studies on the Intermediaries Between the Cities of the Greek Mainland and the Aegean and the Royal Courts in the Hellenistic Period (322-190 BC), Athens.

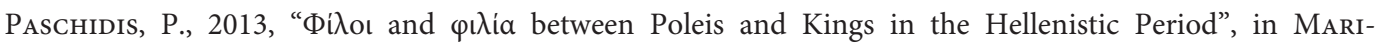
Thornton 2013, p. 283-298.

Patterson, L.E., 2010, Kinship Myth in Ancient Greece, Austin, TX.

Pausch, D., 2018, "Diodoros, the Speeches, and the Reader", in L. I. Hau, A. Meeus, B. Sheridan (eds.), Diodoros of Siciliy: Historiographical Theory and Practice in the Bibliotheke, Leuven et al., p. 473-489.

PePe, C., 2013, The Genres of Rhetorical Speeches in Greek and Roman Antiquity, Leiden-Boston.

Pernot, L., 2005, Rhetoric in Antiquity, Washington, DC.

Piazza, F., 2011, "Pisteis in Comparison: Examples and Enthymemes in the Rhetoric to Alexander and in Aristotle's Rhetoric", Rhetorica 29, p. 305-318.

Piccirilli, L., 2002a, L’invenzione della diplomazia nella Grecia antica, Roma.

Piccirilli, L., 2002b, (ed.), La retorica della diplomazia nella Grecia antica e Bisanzio, Roma.

Poullloux, J., 1974, “Les décrets delphiques pour Matrophanès de Sardes”, BCH 98, p. 159-169.

Rigsby, K., 1996, Asylia. Territorial Inviolability in the Hellenistic World, Berkeley.

Rostovtzeff, M., 1935, “Прójovo»", JHS 55, p. 56-66.

Rubinstein, L., 2013, “Spoken Words, Written Submissions, and Diplomatic Conventions: The Importance and Impact of Oral Performance in Hellenistic Inter-polis Relations”, in KREMmydas-Tempest 2013, p. 165-199.

Rubinstein, L., 2016, "Envoys and Ethos: Team Speaking by Envoys in Classical Greece”, in EdwARds 2016, p. $79-128$.

Russell, D.A., Wilson, N. G., 1981, (eds.), Menander Rhetor, Oxford.

Rutherford, I., 2013, State Pilgrims and Sacred Observers in Ancient Greece: A Study of Theōriā and Theōroi, Cambridge.

SACKS, K., 1986, "Rhetoric and Speeches in Hellenistic Historiography", Athenaeum 64, p. 383-395.

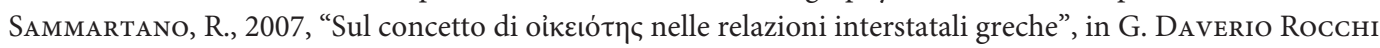
(ed.), Tra concordia e pace. Parole e valori della Grecia antica, Milano, p. 207-235.

Savalli-Lestrade, I., 2017, “Ambassadeurs royaux, rois ambassadeurs. Contribution à l'étude du "métier de roi” dans le monde hellénistique”, in A. Queyrel-Bottineau, M.R. Guelfucci (eds.), Conseillers et ambassadeurs dans l'Antiquité, Besançon, p. 695-718.

ScharfF, S., 2016, Eid und Außenpolitik. Studien zur religiösen Fundierung der Akzeptanz zwischenstaatlicher Vereinbarungen im vorrömischen Griechenland, Stuttgart. 
Shipley, D. G. J., 2018, The Early Hellenistic Peloponnese: Politics, Economies, and Networks 338-197 B.C., Cambridge.

Simonton, M., 2018, “The Local History of Hippias of Erythrai: Politics, Place, Memory, and Monumentality”, Hesperia 87, p. 497-543.

Smith, W. D., 1990, (ed.), Hippocrates. Pseudepigraphic Writings, Leiden et al.

Stavrianopoulou, E., 2013a, (ed.), Shifting Social Imaginaries in the Hellenistic Period: Narrations, Practices, and Images, Leiden-Boston.

Stavrianopoulou, E., 2013b, "Hellenistic World(s) and the Elusive Concept of 'Greekness", in StaVrianopulou 2013a, p. 177-205.

Stork, P., van Ophuijsen, J.M., Dorandi, T., 2000, "Demetrius of Phalerum: The Sources, Text and Translation”, in W. W. Fortenbaugh, E. Schütrumpf (eds.), Demetrius of Phalerum: Text, Translation and Discussion, New Brunswick, NJ, p. 1-310.

TAitA, J., 2004/2005, "Proxenoi "santuariali” all'oracolo di Zeus ad Olimpia. Profilo giuridico e funzioni”, MEP 7/8, p. 87-114.

Teegarden, D.A., 2014, Death to Tyrants! Ancient Greek Democracy and the Struggle Against Tyranny, Princeton.

Thornton, J., 2013, “Oratory in Polybius’ Histories”, in Kremmydas-Tempest 2013, p. 21-42.

Thornton, J., 2014, Le guerre macedoniche, Roma.

VINCI, M., 2008-2009, "Il decreto di Eleutherna e la datazione dei documenti teii di asylia", Hormos n. s. 1, p. 189-211.

Virgilio, B., 2013, "Forme e linguaggi della comunicazione fra re ellenistici e città", in MARI-THORNTON 2013, p. 243-261.

Wallace, S., 2018, "Alexander the Great and Democracy in the Hellenistic World", in M. Canevaro, B. Gray (eds.), The Hellenistic Reception of Classical Athenian Democracy and Political Thought, Oxford, p. $45-72$.

Wooten, C.W., 1973, “The Ambassador's Speech: A Particularly Hellenistic Genre of Oratory”, QJS 59, p. 209-212.

Zecchini, G., 2005, “Ambasciate e ambasciatori in Polibio”, in E. Torregaray Pagola, J. Santos Yanguas (eds.), Diplomacia y autorrepresentación en la Roma Antigua, Vitoria-Gasteiz, p. 11-23 (repr. as "La diplomazia dei Greci e la diplomazia dei barbari”, in G. Zecchini, Polibio. La solitudine dello storico, Roma 2018, p. 87-99).

Zelnick-Abramovitz, R., 2004, “The Proxenoi of Western Greece”, ZPE 147, p. 93-106. 